Kafkasya Calışmaları - Sosyal Bilimler Dergisi / Journal of Caucasian Studies (JOCAS) Eylül / September 2016, Yıl / Vol. 2, № 3

ISSN 2149-9527 (basılı / print) ISSN 2149-9101 (cevrimici / online)

\title{
Ресурсы позднеимперской «русификации»: опыт Центрального Кавказа
}

Елена И. Кобахидзе*

\section{Резюме}

Проблема взаимоотношений центра и окраинных регионов Российской империи всегда отличалась особой остротой. Этнокультурная и социально-политическая мозаичность Российского государства, как и природа российской государственности как таковой, определяли приоритеты в правительственной национальной политике, нацеленной на сохранение единства и целостности страны. Идеологическим основанием формирования имперского универсума служила идея «русификации». В статье обсуждаются вопросы реализации русификаторских устремлений правительства на Центральном Кавказе в административном, образовательном и колонизационном аспектах. Подчеркивается, что административная практика в целом была ориентирована на унификацию местных общественных структур и стандартизацию всего разнообразия форм общественного самоуправления. Документы свидетельствуют, что сфера образования дала образцы позитивной мотивации русификации в местной среде, поскольку именно образование и его база - русский язык - способствовали относительно успешной интеграции местных сообществ в иную цивилизацию. Значительный русифицирующий потенциал имела и переселенческая политика, поскольку русские колонисты не только меняли социально-демографический фон региона, но и несли с собой некий «имперский комплекс».

Ключевые слова: Российская империя, Центральный Кавказ, русификация, унификация, административная практика, образование, переселенческая политика

* Елена Исааковна Кобахидзе - доктор исторических наук, ведущий научный сотрудник Северо-Осетинского института гуманитарных и социальных исследований им. В.И. Абаева ВНЦ РАН и Правительства PCO-A. E-mail: elena_k11@mail.ru. Тел.: +7 (928) 0733592 


\title{
Resources of the Late Imperial "Russification": The Case of the North Caucasus
}

\author{
Elena I. Kobakhidze ${ }^{*}$
}

\begin{abstract}
The problem of relationships between the center and outlying regions of the Russian Empire had always particular acuteness. Both historically determined ethno-cultural and socio-political mosaicity of Russia and nature of the Russian statehood defined priorities of governmental national policy, aimed at preserving unity and integrity of the country. An ideological basis for forming the imperial universe was the idea of "Russification". The article discusses the issues of fulfillment of Russification purposes of the Russian government in the Central Caucasus in administrative, educational and colonizational aspects. It is emphasized that administrative practice in general was oriented to unification of the local social structures and standardization of the variety of forms of selfmanagement. As it follows from the documents, an educational sphere gave patterns of positive motivation for Russification among local population as the very education and its basis - the Russian language - promoted quite successful integration of local societies in other civilization. The resettlement policy also had considerable Russifying potential as the Russian colonists not only changed the regional socio-demographic background, but brought with them a certain "imperial complex".
\end{abstract}

Keywords: Russian Empire, Central Caucasus, Russification, unification, administrative practice, education, resettlement policy

* Elena Isaakovna Kobakhidze - doctor of historical sciences, leading researcher, V.I. Abaev North-Ossetian Institute for Humanitarian and Social Studies of VSC of RAS and the Government of North Ossetia-Alania. E-mail: elena_k11@mail.ru.Tel.: +7 (928) 0733592 


\section{К постановке проблемы}

В ходе становления и развития российской государственности возникали и решались задачи поддержания единства и целостности страны. Этнокультурная мозаичность российского общества, обусловленная сосуществованием в единых административно-территориальных границах самых разнообразных моделей социально-политической организации общественных систем, во многом определяла выбор приоритетов в национальной политике Российской империи в окраинных провинциях.

Основным ее содержанием было стремление к формированию имперского универсума, интегрирующего множественные микросоциумы в едином политическом и культурном пространстве. Идеологическим основанием интеграционной политики Российского государства выступала идея «русификации», имевшая разный социальный смысл в разные периоды истории взаимоотношений центра с национальными перифериями. На первом этапе (в условных хронологических границах последней четверти XVIII - 80-х гг. XIX в.) подразумевалось политическое единство в установленных государством административных границах, объединение разнородного населения в широком гражданско-правовом поле на основе общегосударственного законодательного права; цели "обрусения" соотносились с ценностно-нормативными категориями и трактовались как исполнение «цивилизаторской миссии", в ходе которой чуждая ментальность приобщалась к идее «гражданственности». Однако затем, начиная с 80-х гг. XIX в., когда Россия уверенно двинулась по пути ускоренной модернизации, перед правительством встала задача объединения общества на основе единой имперской идеологии, преодолевающей «дробность социокультурного конгломерата» и унифицирующей множественные микросоциумы в некоем имперском универсуме. Прагматизм имперской политики по отношению к окраинам сводился теперь к поиску «общих, универсализующих принципов и ценностных ориентаций» как основы «единства и неделимости». В связи с этим получила развитие идея формирования культурно-языкового единства, с 
выраженными доминирующими позициями языка и культуры русского населения как основы складывания общеимперской наднациональной идентичности ${ }^{2}$. Сформулированная в конце XIX в. идея «нации» подталкивала официальные верхи к разработке политики, направленной на «формирование однородной массы граждан, гомогенизированной... в лингвистическом и административном отношении» ${ }^{3}$.

\section{Административное измерение «русификации»}

В немалой степени решение задач «русификации» отводилось административной практике, нацеленной на переустройство местных общественных структур и стандартизацию всего разнообразия организационных форм самоуправления. Этот процесс подразумевал широкое распространение в местной среде как государственных административно-правовых учреждений, так и принципиально иных стратегий социальноэкономического поведения и связанных с ними культурных ценностей, которые, по сути, характеризовали совершенно иную модель социальных отношений, а шире - иную цивилизацию. Эта деятельность имела столь выраженную направленность, что в литературе прочно утвердилось понятие «административная русификация ${ }^{4}$.

Наиболее очевидный эффект от государственноадминистративной деятельности проявился на низовых социальных уровнях - в горских сельских общинах, где формированию и реорганизации органов сельской администрации изначально уделялось особое внимание (свидетельством чему, например, проект волостного управления в Осетии, еще в 1816 г. предложенный А.П. Ермоловым 5 , специальные разделы «Инструкции для окружных начальников» 1860 г., разработанной наместником А.И. Барятинским ${ }^{6}$, и Положения о Терской области 1864 г.7), хотя практические результаты этой деятельности появились лишь после завершения Кавказской войны и введения на Центральном Кавказе на рубеже 60-70-х гг. XIX в. «гражданского устройства» ${ }^{8}$. Поставив перед собой задачу скорейшего «обрусения» края, правительство шло по пути унификации и стандартизации 
управления на всем Северном Кавказе и приведения местных форм самоорганизации и самоуправления в соответствие с теми, что существовали в центральных районах империи. При этом создание низовых административных институтов, являвшихся неотъемлемой частью целостного государственноадминистративного механизма, каковой и являлась административная система, отвечало логике развития всякой формальной организации: низовой аппарат также строился на унифицированных принципах рационализации и бюрократизации управления, регламентировавшего все стороны общественной жизни местного населения9.

Очевидно, что подобное вмешательство в общинный быт горцев было чревато серьезными осложнениями для местной администрации, которая предлагала взаимоисключающие модели разрешения конфликтной ситуации, в той или иной степени успешно пытаясь приспособить механизмы регулирования социальных процессов, существовавшие в горских обществах, к собственным целям и задачам, подразумевавшим по сути интеграцию разнородного населения в едином гражданско-правовом поле. Одним из таких относительно «безболезненных» механизмов адаптации местных общественных систем к новым принципам администрирования стали трансформированные в общественные сходы патриархальные народные собрания, представлявшие прежде важнейшее звено в системе общественного самоуправления в горской общинной среде. Между тем, использование в управленческой деятельности традиционных структур или их элементов носило выборочный, даже спонтанный, характер и сохраняло в некоторой мере лишь внешние институциональные формы ранее существовавших патриархальных институтов, относительная же непротиворечивость интеграционных процессов была обусловлена пересечением в общественной практике горской сельской общины «старого» и «нового» социального порядка.

Снизить конфликтную напряженность в сельских обществах призваны были и проекты, предполагающие некоторое послабление требованиям населения (например, о выборах 
сельских должностных лиц самими обществами из числа их представителей ${ }^{10}$ ); с другой же стороны местные власти, озабоченные «подъемом нравственного и культурного уровня» анархично настроенного местного населения, стремились как можно скорее «привязать» его к общегражданским установлениям, видя в подобных уступках угрозу авторитету российской власти и ее важнейшим институтам ${ }^{11}$.

Переняв некоторые европейские формы модернизационного развития, но при этом так и не изжив традиционализм общества ни в период Великих реформ, ни даже спустя десятилетия, власть стремилась низы инородческих сообществ окраинных провинций наделить чертами крестьянского сословия, приводя таким образом всю пеструю массу аграрного населения окраин к единому сословному «стандарту», параметры которого были заимствованы у русского крестьянства центральных областей как основного «ядра» империи ${ }^{12}$.

Выстраиваемый на низовых уровнях административного аппарата, новый социальный порядок в организационном плане служил эквивалентом имперского комплекса, который несли с собой колонисты и который, имея поначалу в качестве духовной составляющей идею православия, со временем трансформировался в политическую идеологему «гражданственности» как общей национальной идеи, выступавшей обоснованием целостности государства, его «единства и неделимости».

И это в контексте Российской империи выглядит далеко не случайным. Именно стремление к формированию некой универсальной общности, интегрированной на основе идеи единой государственности, воплощавшейся в формальном равенстве всех ее граждан, являлось качественной характеристикой Российской империи, в рамках которой многочисленные микросоциумы инкорпорировались в имперскую структуру - универсальную систему со своим типом социализации, который до известных пределов не исключал и традиционные способы организации жизни ${ }^{13}$. Несущим каркасом империи служил административный аппарат, выстроенный на жестких принципах вертикальной иерархии ${ }^{14}$. 
Именно управленческие практики и механизмы конституировали общеимперское социальное пространство, усиливая и без того доминирующую этатистскую составляющую в российской государственности и оказываясь основными каналами воздействия государства на общество и его основные институты, включая религию.

\section{Язык и школа: формирование механизмов адаптации}

Вторая половина XIX в. стала периодом созревания новых идеологических формул поддержания имперского порядка и социальной стабильности, тем более востребованных, чем интенсивнее в стране шли внутренние трансформационные процессы, завязанные сначала на реформах 60-х гг., а затем - на т.н. контрреформах 80-х. Начало XX века, ознаменовавшего системный кризис империи, дало новый импульс к разработке идеологии национальной стабильности, выраженной в понятии «единой и неделимой России», в которую активно включились разные слои российского общества. Актуализация поиска новых обоснований имперской (общеимперской) идентичности обусловливалась еще и пестрым в этнокультурном и конфессиональном аспектах составом населения, что на деле означало высокую степень конфликтогенности процессов имперской унификации. Гасить назревавшие и подавлять вспыхивавшие в связи с этим социальные конфликты являлось в подобных обстоятельствах не столько задачей государства по установлению общественного порядка, сколько одной из важнейших функций Империи, ориентированной на формирование новых социальных мотиваций на основе "тождества интересов" в экономическом, политическом и социальном отношениях.

Основанием подобного тождества призвана была стать национальная идея, обосновывавшая ведущую роль в объединении имперского социума «великорусской народности» как «ядра империи», занимавшего центральные земли и окруженного окраинами с инородческим населением, и, соответственно, всего того, что это «ядро» символизировало. Наиболее емко эта правительственная установка уже в начале 
80-х гг. XIX в. прозвучала в формулировке председателя Комитета министров Н.Х. Бунге: «Император Александр III справедливо признал, что в русском государстве должны господствовать: русская государственность, т.е. русская государственная власть и русские государственные учреждения (конечно, примененные к бытовым условиям инородцев и окраин), русская народность, т.е. освобождение последней от иноплеменного преобладания, русский язык, как общий государственный, и, наконец, уважение к вере, исповедуемой русским народом и его государем» ${ }^{15}$. Особая роль в распространении и утверждении национальной идеи отводилась русскому языку как языку общегосударственному, который (наряду с православием) воспринимался в качестве одного из ведущих интегрирующих факторов, хотя они, по мысли А. Каппелера, и не являлись «конститутивными» для российского государства и общества. Главная роль в государственной политике по отношению к нерусскому населению принадлежала все же стабилизации господствующего режима и лояльности нерусских подданных по отношению к государям и их династиям ${ }^{16}$.

Включение окраинного населения в общеимперское пространство означало не только вовлечение его в политикоэкономический строй империи, но предполагало в конечном итоге «окончательное создание гармонического единства» ${ }^{17}$, оформленного по единым социокультурным стандартам, заданным «великорусской народностью». Впрочем, несмотря на однозначность намерений, то, каким все же образом достичь «гармонического единства», всегда было большим вопросом для правительствующих кругов. Р. Джераси справедливо подмечает: «Хотя самодержавное правительство могло проявлять постоянство и решимость в собственных действиях и в политике... взгляды российских властей и общества относительно ассимиляции даже малого числа народов империи в одном (хотя и не типичном) регионе (речь идет о Среднем Поволжье. - Е.К.) были чрезвычайно амбивалентны, изменчивы, неопределенны и противоречивы... Не было согласия по поводу того, в какой степени, в каком порядке, в 
какое время и в каком месте следовало бы наделять чертами "русскости" нерусские народы империи». По мнению исследователя, проблема состояла в отсутствии общепринятого определения «русской нации» («Russian nationality»), в «официальных» версиях которого сочетались «такие элементы, как религия, язык, управление, обычаи, политическая лояльность, расовая принадлежность и история в еe бесчисленных проявлениях» ${ }^{18}$.

Отметим в связи со сказанным, что при анализе процессов русификации национальных окраин Российской империи следует различать процессы «огосударствления» («распространения начал цивилизации» - в терминологии российских администраторов) от процессов ассимиляции, аккультурации, колонизации и пр. И если ассимиляция подразумевает процесс уподобления, включения в новую общность, усвоения нового мировоззрения и, что является, пожалуй, наиболее существенным в характеристике этого явления, «отсутствие конфликта по вопросам ценностей и власти ${ }^{19}$, то аккультурация связывается с процессом усвоения новых культурных моделей, заимствованных в ходе контактов с другим сообществом, и, таким образом, не затрагивает глубинных пластов национально-культурной идентичности. Происходя зачастую в условиях военного и политического доминирования, такая вынужденная аккультурация приобретает выраженный инструментальный характер, становясь одной из форм адаптации, при которой в адаптирующемся социуме формируются стратегии индивидуального и группового поведения, ориентированные по большому счету на перспективу и помогающие общности наиболее безболезненно осваивать пространство доминирующей культуры, находя в нем приемлемые для себя ниши.

В силу масштабов и культурно-языковой гетерогенности Российской империи приоритеты центральной власти на окраинах были связаны, скорее, не с достижением полной ассимиляции и утверждением общей для всего населения идентичности, сколько с приобретением лояльности, причем не столько политической, сколько выраженной в культурных 
формах и связанной «с ориентацией на имперский центр как приоритетный источник культурных образцов и влияний» ${ }^{20}$. Эту грань проводили и идеологи правительственной политики "сближения / или слияния инородцев с русскими»: под слиянием понималось не поглощение, а «порядок вещей, при котором две народности различного происхождения должны находиться под влиянием одного и того же экономического и социального строя, повиноваться одним и тем же всеобщим законам и следовать тем же побуждениям ${ }^{21}$. Речь, таким образом, должна идти о создании механизмов, нацеленных на формирование локальными сообществами позитивной мотивации русификации, обеспечивающей более или менее успешную адаптацию к новым формам хозяйственной и социально-политической жизни в условиях русифицирующего давления государства.

И если административное обустройство региона в целом выступало все же деструктивным фактором по отношению к местным традиционным социумам, то сфера образования дала образцы позитивной (инструментальной) мотивации русификации населения Центрального Кавказа, сглаживающей издержки политики имперской унификации и позволяющей горцам войти в мир «большого общества». Между тем, поскольку политическая составляющая, подразумевавшая утверждение российской государственности на национальных окраинах с одновременной интеграцией их населения в общегосударственный организм, в той или иной мере присутствовала во всех аспектах правительственной политики на Кавказе, то и сфера образования, которому изначально отводилась совершенно особая роль средства воспитания граждан единой империи, не стала исключением.

Как в целом на Кавказе, так и в его отдельных субрегионах (в частности в Осетии) образовательная политика в силу ряда обстоятельств имела свою специфику.

Во-первых, Кавказ являлся регионом, где русский язык изначально занял безоговорочные доминирующие позиции. Поначалу государственный язык проникал в местную среду посредством православия, ставшего преимущественным 
каналом идеологического воздействия на местные сообщества и отстаивавшего свой приоритет в деле просвещения местных народов, преследуя по сути миссионерские цели. В процессе формирования общеимперской идентичности, на что, собственно, и были нацелены усилия правительства при проведении «русификаторского» курса на «инородческих» окраинах, именно религии отводилась роль одного из ведущих интегрирующих факторов в силу ее символической роли особого (сакрального) центра Российской империи. Наряду с открытой пропагандой христианства среди народов Центрального Кавказа (из которых только осетины могли, и то с достаточной долей условности, считаться христианами православного исповедания), специально созданная для этих целей еще в 1745 г. Осетинская духовная комиссия активно занялась просветительской деятельностью. Пришедшее ему на смену «Общество восстановления православного христианства на Кавказе» $(1861)^{22}$, объединившее большинство школ духовного ведомства, даже поначалу находилось в ведении наместника, и лишь с 1885 г. оказалось окончательно вверено экзарху Грузии и передано в непосредственное подчинение Св. Синоду ${ }^{23}$.

С созданием осетинской школы в Моздоке (1764), где учебным процессом заведовала Осетинская духовная комиссия и где начальное обучение проходило на родном языке, началась подготовка лояльной центральной власти местной элиты. Образовательная деятельность церковных учреждений всецело поддерживалась центральным правительством и местной администрацией, где начальное школьное образование (в том числе ведущееся и в приходских школах) рассматривалось как эффективный механизм идеологического воздействия в деле «образования юношества». Лишь на рубеже XIX-XX вв. приоритет духовного ведомства в сфере народного образования стал предметом полемики, вынесенной на обсуждение в Государственный совет, где было решено, что «дальнейшее расширение прав духовного ведомства по заведыванию народным образованием “едва ли может быть оправдано с точки зрения потребностей государства и задач самого духовного ведомства". Генерал-адъютант П.С. Ванновский в 
отзыве от 25 сентября 1901 г. признал необходимым: установить правильную точку зрения на права и обязанности обоих ведомств (Св. Синода и Министерства внутренних дел - Е.К.) и на взаимные между ними отношения, уравнять права церковных школ и школ учебного ведомства, в целях же единства управления народным образованием создать не только мелкие местные органы из представителей разных ведомств, но и общие органы уездные, губернские и центральные. 18 января 1902 г. состоялось Высочайше утвержденное постановление Государственного Совета, долженствующее служить исходным пунктом новых законодательных работ: обер-прокурору Святейшего Синода и министрам Народного Просвещения и Внутренних Дел поручено сообразить вопрос об объединении деятельности этих ведомств в области народного обучения и предположения свои внести в Государственный Совет» ${ }^{24}$.

Сами церковнослужители, хотя и рекрутировались из местного населения, обучались в русских учебных заведениях на русском же языке, что обеспечивало православию выполнение, помимо собственно духовных, также функции пропаганды идей российской государственности и законности в местной «иноверной» среде.

Во-вторых, образование для горцев (и осетин в особенности) становилось мощным ресурсом социализации в общеимперском пространстве, выводившим общинника за пределы традиционной повседневности и открывавшим возможности для успешной интеграции в иную цивилизацию, одновременно обеспечивая чувство сопричастности намного более широкой социальной общности, чем любой кровнородственный или территориально-родственный патриархальный коллектив. Вполне реальными становились карьерные перспективы и на местном уровне: знание русской грамоты не только значительно поднимало общественный вес общинника в глазах односельчан - владея русским языком, рядовой горец мог повысить и собственный социальный статус, заняв привлекательную должность писаря в сельской администрации либо став учителем, дьяком или даже священником ${ }^{25}$. Вот почему сами жители нередко изъявляли желание, «чтобы в их селение был 
назначен непременно русский учитель», мотивируя это тем, что в таком случае «их дети скорее научатся русскому языку» ${ }^{26}$, и в действительности в подобных обстоятельствах русский язык усваивался лучше, что было весьма ценимо горцами ${ }^{27}$.

В-третьих, показательна роль русского языка, который всегда рассматривался как «главнейший фактор объединения разноплеменного коренного населения края с Империею» ${ }^{28}$. Закрепившийся за русским языком приоритет в процессе преподавания в местных учебных заведениях не только среднего, но и начального уровня, в целом развивал тенденцию к ослаблению, а затем и отказу от регионалистских установок по отношению к Кавказу и его населению, наметившуюся после ухода с поста наместника М.С. Воронцова ${ }^{29}$. Поставленная Николаем I перед учебным ведомством цель - «сблизить устройство учебных заведений Кавказского округа с тем устройством, которое введено по подобным заведениям внутренних губерний и таким образом постепенно ввести на Кавказе и за Кавказом ту же систему народного образования, которая существует в прочих частях государства» - была обозначена в качестве основной еще в «Положении о Кавказском учебном округе» 1853 г. ${ }^{30}$, а затем была включена в число первоочередных в программу преобразований Кавказского края наместника великого князя Михаила Николаевича, по глубокому убеждению которого «только духовное оружие может довершить и скрепить окончательно покорение всякой народности» ${ }^{31}$. При этом в отношении учебной части на Кавказе уже не предполагалось никаких отдельных мер, учитывающих особенности края, напротив программа наместника была ориентирована на «окончательное сближение всей системы образования на Кавказе с принятою Министерством Народного Просвещения» ${ }^{32}$.

«Положение о начальных народных училищах» (1864) объявляет уже русский язык единственным языком преподавания предметов, включенных в обязательный курс (Закон Божий, чтение по книгам гражданской и церковной печати, письмо, арифметика, церковное пение - «там, где преподавание его будет возможно») ${ }^{33}$. В продолжение этого 
курса по инициативе наместника в 1867 г. утверждается особое «Положение об учебной части на Кавказе и за Кавказом", закрепившее принципы унификации школьного дела на Кавказе и в других частях империи. При этом, однако, Положение допускало некоторые компромиссы относительно русского и местных («природных») языков: увеличение количества учебных часов, отведенных на преподавание русского языка, некоторым образом компенсировалось разрешением преподавания местных языков, включенных в учебный курс в качестве предмета обучения в начальных училищах ${ }^{34}$. А со времени введения Правил о применении к учебным заведениям Кавказского учебного округа общих училищных уставов Министерства народного просвещения (1873) на низшие казенные, общественные и частные учебные заведения (не исключая и церковно-приходские школы иноверческих вероисповеданий) распространяется общий закон относительно обязательности преподавания русского языка, а также русской истории и географии на русском же языке в тех из них, где эти предметы были предусмотрены образовательными программами ${ }^{35}$. Школы духовного ведомства, в соответствии с утвержденными в 1874 г. «Правилами начальных приходских школ Общества восстановления православного христианства на Кавказе ${ }^{36}$, также были ориентированы на распространение русского языка (в отличие от Правил редакции 1863 г., где «природный язык» еще значился языком начального обучения ${ }^{37}$ ). Издание в 1897 г. Министерством народного просвещения примерных программ преподаваемых в начальных училищах дисциплин окончательно подтвердило позиции русского языка как единственно возможного языка обучения даже на начальных уровнях.

Местный язык оставался лишь предметом изучения и в духовных училищах (например, Ардонском Александровском духовном училище, созданном в 1887 г. $^{38}$, с 1895 г. преобразованном В Ардонскую миссионерскую духовную семинарию), где готовились приходские священники и учителя для церковно-приходских школ. В целом же, судя по отчету попечителя Кавказского учебного округа за 1903 г., из 2086 
начальных школ в 1928 школах (92,3\%) языком преподавания служил русский язык, и лишь в 158 школах родной язык допускался в помощь при изучении русского языка ${ }^{39}$.

В итоге Северный Кавказ остался в стороне от полемики, разгоревшейся в 70-80-хгг. о путях начального образования «инородцев», и здесь не были введены правила 1870 г. «О мерах к образованию населяющих Россию инородцев», что мотивировалось не только полиэтничным и поликонфессиональным составом населения региона, но, главным образом, общегосударственными интересами, не допускающими «нежелательное усиление племенных и религиозных различий» в случае национализации начальной школы $^{40}$. В этом контексте учреждение сети начальных школ с передачей им «материнских» функций (использование родного языка, сохранение и поддержка в образовательном процессе конфессиональных предпочтений) не снимало вопроса об угрозе стабильности основ государственного «единства», чреватой сепаратистскими устремлениями, обострившимися на Кавказе на рубеже XIX-XX в. ${ }^{41}$

Вместе с тем русский язык являлся (и воспринимался!) не только языком государственным, но также $и$ языком межэтнического общения, посредником в межкультурной коммуникации. Следствием этого стало не просто заимствование, но усвоение новых образцов организации жизни и связанных с ними ценностей, вовлекающих человека в круг современных отношений и значительно расширяющих сеть его социальных связей в лоне иной культуры. Особое стремление к усвоению русского языка выказывало население Осетии, большая часть которого охотно отдавала своих детей «в станицы казакам для обучения русской грамоте... Ныне не редкость встретить осетина, умеющего, хотя и плохо, но написать чтолибо, а говорящий по-русски уже не удивляет никого», рапортовал начальник Владикавказского округа областному начальству еще в 1868 г., что давало ему основания требовать начинать обучение в осетинских школах «прямо с русского языка»" ${ }^{42}$. Нередки были и случаи, когда осетины и ингуши отдавали своих детей в услужение городским жителям без 
всякой платы, но с единственным условием - выучить ребенка читать, писать и говорить по-русски ${ }^{43}$. И уже к середине 90-х гг. XIX в. главноначальствующий гражданской частью на Кавказе С.А. Шереметев в своей Всеподданнейшей записке не без гордости констатировал, что успехи его предшественников на поприще гражданского управления краем, следовавших «высочайшим предначертаниям в отношении этой окраины, - в установлении полного слияния ее с остальными частями нашего обширного отечества», были столь внушительными, что большая часть Северного Кавказа стала мало чем отличаться от многих коренных частей империи благодаря «преобладанию русской народности» и «значительному сравнительно распространению русского языка среди племен, населяющих Кавказ» ${ }^{44}$.

Наконец, на Центральном Кавказе всегда был высок спрос на образование и, соответственно, учительские кадры, нехватка которых для кавказской школы имела хронический характер. Еще в начале 60-хгг. «Журнал Министерства народного просвещения» сетовал: «Но где взять учителей, да таких учителей, которые бы вносили в народ не одно знание грамоты, но умственное образование, христианский характер, и те гражданские правила жизни, на которых покоится благоденствие государства» ${ }^{45}$. Помимо этого, задачи скорейшего мирного освоения края, выступившие на первый план после окончания Кавказской войны и последовавшего затем административного переустройства Северного Кавказа, актуализировали теперь и проблему формирования слоя управленческой бюрократии, и школа, по мысли реформаторов, должна была сыграть важную роль в подготовке местных управленческих кадров, которые могли бы помочь культурному слиянию кавказских окраин с российской метрополией ${ }^{46}$. Школа «для народа» была объявлена «краеугольным камнем нравственного и материального благосостояния всего края» ${ }^{47}$.

Частичное разрешение проблемы учительских и административных кадров в пореформенный период связывалось с «Положением о Кавказских воспитанниках в высших и специальных учебных заведениях Империи» $(1868)^{48}$, разработанном в целях «снабжения края специалистами по 
некоторым отраслям администрации и деятельности общественной и промышленной» ${ }^{49}$. На «местах» подготовкой педагогических кадров занималось Общество восстановления православного христианства на Кавказе, в ведении которого находилось Владикавказское духовное училище (1836-1863), Тифлисская семинария, через которую прошло все осетинское духовенство, учительская школа в Тифлисе (открытая в 1866 г. и в 1872 г. преобразованная в Александровский учительский институт) и Кубанская учительская семинария, впрочем, даже в совокупности не отвечавшие реальным потребностям в количественном и качественном составе учителей. И спустя почти полстолетия в администрации Терской области с сожалением отмечали, что «среди туземцев почти совсем нет учителей. Приходится назначать в туземные училища русских учителей и учительниц, которые начинают преподавание прямо на государственном языке. Те же немногие из туземцев, которые получили учительское звание, неохотно идут в туземные училища и предпочитают добиваться мест в русских, преимущественно станичных училищах ${ }^{50}$.

Предпринятое со времени учреждения Терской области относительное расширение сети начальных образовательных учреждений с программами, отвечающими русификаторским устремлениям правительства, одновременно удовлетворяло (хотя и в значительно меньшем, чем требовалось, объеме) образовательным запросам самого населения. Частым явлением общественной жизни горцев стали выносимые на сельских сходах общественные приговоры об открытии приходских школ ${ }^{51}$. Личное внимание высшей администрации края к народным школам поощряло местные сообщества к устройству новых училищ, а «Кубанская учительская семинария стала переполняться стипендиатами сельских и станичных обществ» ${ }^{52}$.

Растущие потребности горцев в образовании нашли отклик у нового кавказского наместника И.И. Воронцова-Дашкова, программа "умиротворительной политики» которого содержала четко сформулированный план по организации народного образования в крае на всех его уровнях, включая высшее образование ${ }^{53}$. 
Рост числа начальных образовательных учреждений в Терской области к концу первого десятилетия XX в. интерпретировался областной администрацией как показатель "особого подъема и запроса на начальное образование». «Казенные ассигнования преимущественно направлялись на туземные селения,- отмечено в отчете начальника Терской области за 1913 г.- Большинство вновь открытых школ принадлежит этим селениям, именно: среди кабардинцев открыто 22 школы, осетин - 17 школ, ингушей - 15, чеченцев 35, всего 89 школ. Отчетный год должен быть отмечен как показание особого подъема и запроса на начальное образование. Просьбы и ходатайства об открытии школ получались в дирекции со всех сторон, в том числе и от туземного населения. На первом месте в этом отношении стоят чеченцы и кабардинцы и затем осетины и ингуши. И только недостаточное ассигнование средств из государственного казначейства обусловливает малую возможность полного удовлетворения этих ходатайств» ${ }^{54}$.

Анализ процессов, связанных с реализацией образовательной политики на Центральном Кавказе во второй половине XIX начале XX в., приводит к следующим основным выводам. Прежде всего, оценивая сложившуюся в сфере образования в начале XX в. ситуацию в целом, следует, пожалуй, обратить внимание на ее неоднозначность. С одной стороны, образовательная практика правительства в регионе всегда имела определенный политический подтекст, будучи ориентирована на культурно-языковую ассимиляцию местного населения. Но с другой стороны, откровенные русификаторские установки в деле народного просвещения парадоксальным образом способствовали консолидации национальной интеллигенции и кристаллизации в общественном сознании, выразителем которого являлись ее лучшие представители, идеи национального языка как центрального ядра национальной культуры и понимания необходимости повышения общественного статуса родного языка ${ }^{55}$. Особенно ярко эти процессы протекали в Осетии, и исследователи отмечают по этому поводу: «Поворот традиционного общества к 
просвещению, специализация отдельных сфер культурной деятельности, появление профессиональной литературы и искусства - все это происходило на фоне национальной консолидации и осознания национальных интересов. Именно в этом историческом и культурном контексте протекала деятельность и формировалась мотивация осетинских просветителей середины XIX В.» ${ }^{56}$. Сформулированные ими задачи поддержки родного языка ${ }^{57}$ получили частичное разрешение на волне общей переориентации управления регионом в сторону регионализации (после учреждения в 1905 г. Кавказского наместничества), что сказалась и на принципах организации преподавания в местных школах ${ }^{58}$, в программу которых осетинский язык был введен в качестве обязательного ${ }^{59}$.

Вместе с тем, можно с уверенностью говорить об успешности русификации, состоявшейся не столько благодаря целенаправленным действиям соответствующих официальных ведомств и учреждаемых ими образовательных институтов, сколько ввиду отсутствия на тот момент реальных условий и механизмов повышения статуса родного языка, его утверждения во всех сферах общественной жизни наравне с общегосударственным. Нехватка учебников, квалифицирован-ных педагогических кадров для начальной школы, разнообразной и доступной литературы на родном языке, наконец, весьма ограниченная сфера бытования объективно законсервировала положение национального языка в качестве вспомогательного, обеспечивая русскому языку широкое проникновение в местную среду и формируя в ней настоятельную потребность в его изучении.

В числе факторов, предопределивших инструментальный характер мотивации к усвоению русского языка, можно выделить следующие. Прежде всего, русский язык являлся языком власти, и овладение им значительно повышало социальный статус человека в его макро- и микросоциуме; знание русского языка открывало для горца перспективы выхода за пределы традиционности и освоения намного более широкого социального пространства. Новый социальный контекст, в котором оказывались местные традиционные общества, обеспечивал русскому языку функции посредника в 
межэтническом взаимодействии и межкультурной коммуникации. Наконец, отмечаемое среди горцев (и в особенности осетин) стремление к освоению русского языка являлось адаптивной реакцией на новые и всегда острые социальные вызовы, смягчающей чувство психологического дискомфорта, неизбежного в условиях давления государства и его основных институтов на традиционную повседневность.

\section{Русифицирующий потенциал колонизации}

В активной правительственной политике «обрусения» кавказской окраины действия административно-правового характера в течение всего периода проникновения империи в регион тесно переплетались с мероприятиями по колонизации здешних территорий, результатом которых стало не только хозяйственное освоение мигрантами местных земельных угодий, но и изменение его социально-демографического фона. Запустив механизм внутренней колонизации в кавказском направлении еще во времена Екатерины II, правительство явно обозначило стремление закрепиться на далекой окраине, включив ее территорию во внутренние российские пределы как в административном, так и в социокультурном отношениях. И если первое могло быть осуществлено в ходе официальных правительственных мероприятий, опирающихся на соответствующую законодательно-правовую базу (т.е. путем собственно колонизации, в основе которой лежат прежде всего политические интересы государства), то второе требовало не только иных подходов (более гибких и одновременно более разнообразных, «цивилизационных» - в терминологии кавказского наместника великого князя Михаила Николаевича) $)^{60}$, но и времени, что в позднеимперском дискурсе трактовалось в терминах «русификации». Отметим, что нередко понятие «колонизация» смешивалось с понятием «переселение», хотя и то, и другое имело самостоятельный социальный смысл: переселение происходило в силу собственного миграционного потенциала у населения, стремившегося таким образом решить свои частные проблемы; колонизация же в большой степени связывалась с 
искусственным регулированием миграционных потоков в целях удержания завоеванных территорий и расширения государственного пространства. Однако достижение военнополитических целей на окраинах империи и выселение из центральной России малоземельных крестьян на «окраинные пустыри» с целью их заселения привели к тому, что «колонизация переплелась с переселением» ${ }^{61}$.

Исходя из сугубо политических задач расширения "русского» пространства империи, власти поддерживали переселение на Кавказ и в Предкавказье «русского элемента», поначалу представленного казачьим сословием, а с 60-х гг. XIX в. (в дополнение к военно-казачьей колонизации) - уже обычными крестьянами из центральных российских губерний ${ }^{62}$. Проведение в 1861 г. крестьянской реформы открывало для освободившихся от крепостной зависимости крестьян перспективы для своего земельного устройства, мотивируя их миграционные устремления. С другой стороны, крепко устроенному "русскому элементу» в новоприобретенной и недружелюбно расположенной окраине определено было служить надежной социальной опорой для государственных административных преобразований. Помимо того, предполагаемый «русифицирующий» потенциал переселенцев из российской глубинки должен был не только "усилить» русскую составляющую в населении края, но и, как считалось администрацией, оказать «немаловажное нравственное воздействие» на местных жителей. Соответственно поставленной задаче законы и положения о переселении на Кавказ русских поселенцев из центральных губерний страны, принимаемые уже в 80-90-х гг., имели целью «укрепить» русское население региона.

Однако перенаселение края (ощутимое уже в «золотые» для земледельческой колонизации 70-е гг. ${ }^{63}$ ) и истощение его земельного фонда объективно препятствовали скорой реализации правительственных планов. По свидетельству самого министра внутренних дел И.Л.Горемыкина, «ознакомление с данными об имеющемся на Кавказе запасе казенных земель не оставляет сомнения в том, что губернии 
Кавказа не представляют условий, которые позволяли бы рассчитывать на широкое развитие в них русской колонизации, ибо не только сравнительная незначительность находящихся здесь земель, но свойства последних устраняют предположения о направлении сюда усиленного переселенческого движения» ${ }^{64}$.

Тем не менее, вопрос об "усилении русского населения на Кавказе» был поставлен в ряд первоочередных государственных задач, а заселение его выходцами из российской глубинки объявлялось «весьма желательным с точки зрения общих интересов государства» ${ }^{65}$. Министерство внутренних дел считало, что поставленная правительством задача «сводится не к открытию Кавказа для переселения, а к заселению лишь в пределах возможности свободных его земель русскими людьми. Настоящее положение Кавказа, являя с одной стороны недостаточную для столь богато одаренного от природы края густоту населения, а с другой - преобладание исключительно инородческого, и частью даже мало благонадежного населения... не может быть признано нормальным. Вместе с тем не подлежит сомнению, что изменение сего положения возможно и желательно только путем привлечения в край коренного русского населения, которое одно способно содействовать развитию названной окраины в направлении культурного сближения с остальными частями империи... При таких условиях... как бы ни был ограничен существующий на Кавказе запас свободных земель, его надлежит целесообразно использовать для водворения русского населения» ${ }^{66}$. Заняться решением задач, связанных с переселением на Кавказ русских крестьян, настоятельно рекомендовалось местной администрации.

Усилившееся к концу столетия переселенческое движение на Северный Кавказ, в частности в Терскую область, вело к тому, что прибывавшие крестьяне «все более и более» заселяли «свободные земли во всех углах области, занимая как казенные, так и частновладельческие участки ${ }^{67}$. В результате, с одной стороны, ощутимо увеличилась демографическая нагрузка на регион, а с другой - резко сократились причитающиеся на душу населения земельные наделы. Обезземеливание местного 
крестьянства наряду с проблемами с землеустройством новоприбывших переселенцев заставили правительство на рубеже столетий вернуться к «ограничительному» курсу в переселенческой политике на Кавказе и принятию более жестких условий для переселения в этот регион.

Вместе с тем, выработанные в свете новых тенденций временные правила, регулирующие переселенческое движение на Кавказ и составившие основу Положения Комитета министров о разрешении переселений в Ставропольскую губернию и местности Северного Кавказа (1899), давали преимущества русским крестьянам исключительно православного исповедания, которым предоставлялся для заселения «весь свободный наличный запас казенной земли, не состоящей в отводе казенных крестьян», причем пригодность сдаваемых в аренду участков должна была определяться с учетом прежде всего интересов переселенцев и независимо от земельного положения «туземных поселян» ${ }^{68}$. Вместе с тем, «полезными колонизаторами вновь заселяемых местностей» признавались далеко не все русские и православные: в силу вступали дополнительные условия, предписанные циркуляром главноначальствующего гражданской частью на Кавказе от 15 марта 1901 г., - имущественный ценз (приблизительно до 300 руб. на среднюю крестьянскую семью), опыт предшествующего самостоятельного ведения земледельческого хозяйства («хотя и на заарендованных землях»), а также достаточное количество рабочих рук ${ }^{69}$.

Но и эти меры не могли компенсировать отсутствия внятной программы колонизации (о необходимости которой резко говорил наместник И.И. Воронцов-Дашков ${ }^{70}$ ), что привело не только к перенаселению Северного Кавказа и превращению его самого в регион, «выбрасывающий» миграционные потоки (преимущественно в Закавказье), но и к обострению существовавших социальных противоречий, еще более усугублявшихся земельным голодом, от которого одинаково страдали все местные народы, особенно проживающие в нагорной полосе ${ }^{71}$. 
Между тем, правительство по-прежнему уделяло особое внимание русским переселенцам прежде всего как носителям имперской государственности, в чем и выражался особый «государственный интерес» (см., например, переписку министра внутренних дел И.Л. Горемыкина с министром земледелия и государственных имуществ А.С. Ермоловым ${ }^{72}$ ). Администрация Терской области была убеждена, что внимание к нуждам переселенцев и содействие местной власти к «водворению их в известной последовательности - так именно, чтобы целая сеть русских хуторов разъединяла сплошную массу инородческих поселений, - должны служить одним из лучших средств для упрочения в области русской культуры и гражданственности» ${ }^{73}$, а поселение крестьян из внутренних российских губерний «крупными благоустроенными селами, с церквами, школами, торговлей $и$ промышленностью, несомненно, ускорит умиротворение области ${ }^{74}$.

В результате к началу XX в. «земельный вопрос» в крае приобрел уже особенную остроту, став самостоятельным мощным конфликтогенным фактором, наряду с другими обусловившим социально-политическую напряженность В регионе в конце XIX - начале XX в. В то же время, меняя его социально-демографический фон, новопоселенцы из центральной России несли с собой и мощный культуртрегерский потенциал, оказавший заметное влияние на социальноэкономическое развитие края, вступившего на путь ускоренного преобразования всей системы социально-экономических отношений. Знакомство с новыми формами хозяйствования, приобщение к новой культуре производства-потребления, в конце концов, расширившееся географическое пространство обитания в связи с массовым переселением на равнинные земли заставляли горцев искать возможности удовлетворять "рождающиеся новые потребности», отделяя таким образом «факт от принципа, дело от убеждения ${ }^{75}$.

Таким образом, колонизацию следует рассматривать как особый социально-политический феномен, обеспечивающий перспективу "двойного расширения» Российской империи за счет разрастания «имперского ядра» путем присоединения 
окраин не только в территориально-административном, но и в социально-культурном аспектах ${ }^{76}$. Исследователи отмечают, что колонизация - «это в конечном счете попытка приведения мира в соответствие с тем идеалом, который присущ тому или иному народу. Причем идеальные мотивы могут порой преобладать над всеми прочими - экономическими, военными и другими» 77 . Несмотря на то, что русские переселенцы (как казаки, так и обычные крестьяне) «не были ни убежденными агентами имперской власти, ни носителями “цивилизаторской” миссии, ни миссионерами» ${ }^{78}$, они призваны были стать важной «третьей силой» во взаимоотношениях власти и местных сообществ, которая бы придала процессу колонизации имперское измерение. Идеологическая подоплека колонизационных задач заключалась в формировании «большой русской нации» ${ }^{79}$ как политической целостности, идея которой, трактуемая правительственными идеологами как «национальная», в пореформенный период формулируется в виде нового правительственного курса на создание и поддержание «единства и неделимости» Российской империи с единым политическим ядром, окруженном окраинами.

\section{Выводы}

Подводя итоги, подчеркнем, что и в позднеимперский период приоритеты национальной политики России во многом определялись как характером российской государственности, так и конкретными задачами поддержания стабильности правящего режима и сохранения единства и целостности страны в условиях этнокультурной и социально-политической мозаичности российского общества. Для разных регионов империи вырабатывалась своя стратегия, однако едва ли не важнейшей доминантой объединительной политики Петербурга была ориентация на интеграцию разнородного населения в общеимперском пространстве - территориальноадминистративном, социально-политическом и в определенной мере хозяйственно-экономическом.

Совершенно особая роль в решении задач «русификации» была отведена административной практике. «Административная 
русификация» северокавказской окраины, подспудно содержавшая идею модернизации общества и его основных институтов, заключала в себе задачу «вписывания» местного социума в быстро менявшуюся систему горизонтальных и вертикальных общественных связей в самой империи, отражая стремление к упорядочению, определенной степени «институционализации» всего разнообразия отдельно существующих социальных систем, подведение их под некий единый знаменатель. В целом же управленческие практики и механизмы конституировали общеимперское социальное пространство, усиливая и без того доминирующую этатистскую составляющую в российской государственности и оказываясь основными каналами воздействия государства на общество и его основные институты.

Не менее емким ресурсом «русификации» Кавказа являлась колонизация здешних территорий, социальный смысл которой имел несколько важных измерений: русские поселенцы не только меняли социально-демографический фон региона, но и несли с собой некий «имперский комплекс», ядром которого поначалу выступала идея православия, затушеванная затем политически окрашенной идеологемой «гражданственности» как общей национальной идеей, выступавшей обоснованием целостности государства, его «единства и неделимости».

Образцы позитивной (инструментальной) мотивации русификации населения региона, сглаживающей издержки политики имперской унификации и позволяющей горцам наименее болезненно войти в мир «большого общества», дала сфера образования. Русский язык и образование становились мощным ресурсом социализации в общеимперском пространстве, овладение которым выводило человека за пределы традиционной повседневности и открывало перспективы для успешной интеграции в иную цивилизацию, обеспечивая чувство сопричастности намного более широкой социальной общности, чем любой кровнородственный или территориальнородственный патриархальный коллектив.

В целом же для Центрального Кавказа процессы имперской унификации оказались чреваты довольно высоким 
конфликтогенным потенциалом: встреча автохтонных общественных структур с российской государственностью неизбежно сопровождалась ломкой всей системы устоявшихся общественных связей и социальных ролей с одновременным выстраиванием системы новых идентичностей и формированием новых социальных мотиваций, проистекающих из осознания каждым жителем империи принадлежности к единому макромиру.

\section{ПРИМЕЧАНИЯ}

1 Яковенко И. Православие и исторические судьбы России // Общественные науки и современность (ОНС). 1994. № 2. С. 64.

2 Именно этой сферой - культурно-языковой - и ограничивает понятие «русификации» Каппелер, который, исходя из заданных им самим установок, считает, что говорить о целенаправленной «русификации» как содержании российской национальной политики можно лишь начиная с 60-хгг. XIXв., но и тогда, по мнению исследователя, «она не оформилась во всеохватывающую концепцию, которая могла бы совершенно вытеснить наднациональную основную модель» (Каппелер А. Мазепинцы, малороссы, хохлы: украинцы в этнической иерархии Российской империи // Россия - Украина: история взаимоотношений. М., 1997. С. 138).

${ }^{3}$ Хобсбаум Э. Век империи. 1875-1914. Ростов н/Д, 1999. С. 221.

${ }^{4}$ См., например: Russification in the Baltic Provinces and Finland. 18551914 / Ed. Edward C. Thaden. Princeton, 1981; Russification in Tsarist Russia // Edward C. Thaden, with collaboration of Marianna Forster Thaden. Interpreting History: Collective Essays on Russia's Relations with Europe. New York, 1990. P. 211-220; Weeks Th.R. Russification: Word and Practice. 18631914 // Proceedings of the American Philosophical Society. 2004 (December). Vol. 148. № 4. Р. 471-489; Миллер А. Русификации: классифицировать и понять // Ab Imperio. 2002. №2. С. 133-148; Миллер А. Империя Романовых и национализм: Эссе по методологии исторического исследования. М., 2006.

${ }^{5}$ АКАК. T. VI. Ч. 1. C. 685.

${ }^{6}$ Там же. T. XII. C. 1192-1198.

${ }^{7}$ пСЗ-ІІ. Т. XXXVII. Отд. 1-е. №38326. С. 497-502.

${ }^{8}$ См.: ПСЗ-II. T. XLIV. Отд. 2-е. №47847. С. 412-415; T. XLV. Дополнение. ч. 2. №48429a. С. 11-12; Всеподданнейший отчет главнокомандующего 
Кавказскою Армиею по военно-народному управлению за 1863-1869 гг. СПб., 1870. С. 119.

${ }^{9}$ См.: Положение о сельских (аульных) обществах, их общественном управлении и о повинностях государственных и общественных в горском населении Терской области. Владикавказ, 1871.

${ }^{10}$ РГИА. Ф. 919. Оп. 2. Д. 696. Л. 22-22об.; Ф. 919. Оп. 2. Д. 617. л. 222206

${ }^{11}$ См., например: ЦГА РСО-А. Ф. 11. Оп. 11. Д. 2. Л. 59-60, 103-103об., 109-109об.

12 Кобахидзе Е.И. От самоуправления к имперскому порядку: опыт создания низовых управленческих структур на Центральном Кавказе (вторая половина XIX - начало XX в.) // Известия СОИГСИ. 2012. Вып. 8(47) C. 27-28.

${ }^{13}$ Гатагова Л.С. Империя: идентификация проблемы // Исторические исследования в России. Тенденции последних лет. М., 1996. С. 340.

14 Медушевский А.Н. Административные реформы в России XVIIIXIX вв. в сравнительно-исторической перспективе. Научноаналитический обзор. М, 1990; Агаджанов С.Г. Основные черты системы управления национальных окраин России. (Опыт сравнительноисторического анализа) // Национальные окраины Российской империи: Становление и развитие системы управления. М., 1998. С. 351-413.

15 Цит. по: Волхонский М.А. Первая русская революция и восстановление Наместничества на Кавказе // Кавказский сборник. М., 2006. T. 3 (35). С. 87.

16 Каппелер А. Россия - многонациональная империя. Возникновение. История. Распад. М., 1997. С. 120.

17 Цит. по: Кэмпбелл (Воробьева) Е.И. «Единая и неделимая Россия» и «Инородческий вопрос» в имперской идеологии самодержавия // Пространство власти: Исторический опыт России и вызовы современности. М., 2001. С. 206-207.

${ }^{18}$ Geracy Robert P. Window on the East: National and Imperial Identities in Late Russia. Ithaca and London: Cornell University Press, 2001. P. 343-344.

19 Миллер А. Империя Романовых и национализм: Эссе по методологии исторического исследования. М., 2006. С. 58.

${ }^{20}$ Там же. С. 67.

${ }^{21}$ Цит. по: Кэмпбелл (Воробьева) Е.И. Указ. соч. С. 207.

${ }^{22}$ АКАК. T. XII. C. 529-530.

${ }^{23}$ ПСЗ-III. T. V. № 2726. C. 42-46. 
24 Исторический обзор деятельности Министерства народного просвещения. 1802-1902. / Сост. С.В. Рождественский. СПб., 1902. С. 721722.

25 См.: Материалы по истории осетинского народа: Сборник материалов по истории народного образования в Осетии. Орджоникидзе, 1942. Т. V. С. 139.

${ }^{26}$ Отчет начальника Терской области и Наказного Атамана Терского казачьего войска за 1913 год. Владикавказ, 1914. С. 112.

27 Материалы по истории осетинского народа. С. 179.

28 Всеподданнейшая записка об управлении Кавказским краем генерал-адъютанта графа Воронцова-Дашкова. СПб., 1907. С. 103-104.

29 См.: Гатагова Л.С. Правительственная политика и народное образование на Кавказе в XIX в. М., 1993. С. 26-34.

30 пСЗ-ІІ. Т. XXVIII. Отд. 1-е. №27646. С. 498.

31 Всеподданнейший отчет главнокомандующего Кавказскою Армиею по военно-народному управлению за 1863-1869 гг. С. 99.

32 Модзалевский Л. Ход учебного дела в Кавказском крае с 1802 по 1880 год // Памятная книжка Кавказского учебного округа на 1880 год. Тифлис, 1880. Отд. І. С. 41.

${ }^{33}$ пСЗ-ІІ. Т. ХXXIX. Отд. 1-е. №41068. С. 614.

${ }^{34}$ Там же. T. XLII. Отд. 1-е. №44748.

35 Модзалевский Л. Указ. соч. С. 70, 71.

${ }^{36}$ Материалы по истории осетинского народа. С. 134-137.

${ }^{37}$ Там же. С. 118.

38 Там же. С. 244-246; см. также: Всеподданнейший отчет оберпрокурора Святейшего синода К. Победоносцева по ведомству православного исповедания за 1887 г. СПб., 1889. С. 204-207.

39 Миропиев М.О. О применении школьной системы Н.И. Ильминского на Кавказе // Труды особого совещания по вопросам образования восточных инородцев. СПб., 1905. С. 225-226.

${ }^{40}$ Там же. С. 227, 230.

41 Матвеев В.А. Российская универсалистская трансформация и сепаратизм на Северном Кавказе (вторая половине XIX в. - 1917 г.). Ростов н/Д, 2012. С. 333-335; Миропиев М.О. О применении школьной системы Н.И. Ильминского на Кавказе // Труды особого совещания по вопросам образования восточных инородцев. СПб., 1905. С. 229-230.

42 Материалы по истории осетинского народа. С. 129.

43 ЦГА РСО-А. Ф. 12. Оп. 5. Д. 319. Л. 38.

44 Центральный государственный исторический архив Грузии (ЦГИАГ). Ф. 12. Оп. 1., кн. 2. Д. 3132. л. 1-1об. 
${ }^{45}$ Гатагова Л.С. Указ. соч. С. 60.

46 Бзаров Р.С. Очерки истории осетинской школы// Историкофилологический архив. Владикавказ, 2005. № 3. С. 33.

${ }^{47}$ Модзалевский Л. Указ. соч. С. 73.

${ }^{48}$ ПСЗ-ІІ. Т. XLVIII. Отд. 2-е. № 46454.

${ }^{49}$ Там же. С. 404.

50 Отчет начальника Терской области и Наказного Атамана Терского казачьего войска за 1913 год. С. 112.

${ }^{51}$ См., например: Из отчета наблюдателя церковно-приходских школ о состоянии учебно-воспитательной работы в школах Осетии за 1905-6 уч. год // Материалы по истории Осетии. С. 184.

52 Модзалевский Л. Указ. соч. С. 73.

53 Всеподданнейшая записка об управлении Кавказским краем генерал-адъютанта графа Воронцова-Дашкова. С. 113-120.

54 Отчет начальника Терской области и Наказного Атамана Терского казачьего войска за 1913 год. С. 111-112.

55 См., например: Дзасохов Гр. Образовательное и воспитательное значение отечественного языка // Известия Северо-Осетинского научноисследовательского института (ИСОНИИ). Орджоникидзе, 1934. Т. VIII. С. 178-182; Всеподданнейшая записка об управлении Кавказским краем генерал-адъютанта графа Воронцова-Дашкова. С. 107-108.

${ }^{56}$ Бзаров Р.С. Указ. соч. С. 36.

${ }^{57}$ См., например: Петиция учителей школ Северной Осетии, поданная Владикавказскому епископу // ИСОНИИ. Т. VIII. С. 191-192.

58 Всеподданнейшая записка об управлении Кавказским краем генерал-адъютанта графа Воронцова-Дашкова. С. 106-107.

${ }^{59}$ См., например: Материалы по истории осетинского народа. С. 175177.

60 Главнейшие мероприятия по устройству Кавказского края. Тифлис, 1878. С. 3.

61 Ремнев А.В., Суворова Н.Г. «Обрусение» азиатских окраин Российской империи: оптимизм и пессимизм русской колонизации // Исторические записки. 2008. Вып. 11(129). С. 133.

62 См.: «Положение о заселении предгорий западной части кавказского хребта кубанскими казаками и другими переселенцами из России», принятым 10 мая 1862 г. // ПС3-ІІ. Т. XXXVII. Отд. 1-е. №38256; О дозволении русским подданным не войскового сословия селиться и приобретать собственность в землях казачьих войск // Там же. T. XLIII. Отд. 1-е. №45785. 
63 Кабузан В.М. Население Северного Кавказа в XIX-XX веках. Этностатистическое исследование. СПб., 1996. С. 93.

${ }^{64}$ ЦГИАГ. Ф. 12. Оп. 3. Д. 1. Л. 1-1об.

${ }^{65}$ Там же. Л. 1, 2 об.

${ }^{66}$ Там же. л. 1 об.

67 Всеподданнейший отчет Начальника Терской области и Наказного атамана Терского казачьего войска о состоянии области и войска за 1894 год. Владикавказ, 1895. С. 17.

68 Исмаил-Заде Д. Из истории переселения российского крестьянства на Кавказ в конце XIX - начале XX в. // Исторические записки. 1977. Т. 99. С. 332-333.

${ }^{69}$ ЦГИАГ. Ф. 12, оп. 3, д. 63, л. 41об.-42

70 Всеподданнейшая записка об управлении Кавказским краем генерал-адъютанта графа Воронцова-Дашкова. С. 72-76.

71 См.: Труды комиссии по исследованию современного землепользования и землевладения в Нагорной полосе Терской области. Владикавказ, 1908. С. 97-100, 166; Тедтоев А.А. Временнопроживающие крестьяне в Северной Осетии во второй половине XIX и в начале XX вв. Дзауджикау, 1952. С. 27, 28; Цориева И.Т. Пути исповедимые... Из истории основания равнинных поселений на Кавказе в конце XVIII - XIX вв. Владикавказ, 2011.

72 Дякин В.С. Национальный вопрос во внутренней политике царизма (XIX - начало XX вв.). СПб., 1998. С. 558-562, 567.

73 Всеподданнейший отчет Начальника Терской области и Наказного Атамана Терского казачьего войска о состоянии области и войска за 1891 год. Владикавказ, 1892. С. 27.

74 Всеподданнейший отчет Начальника Терской области и Наказного атамана Терского казачьего войска о состоянии области и войска за 1894 год. Владикавказ, 1895. С. 17.

75 Всеподданнейший отчет главнокомандующего Кавказскою Армиею по военно-народному управлению за 1863-1869 гг. СПб., 1870. С. 117.

76 Горизонтов Л.Е. «Большая русская нация» в имперской и региональной стратегии самодержавия // Пространство власти: исторический опыт России и вызовы современности. М., 2001. С. 130.

77 Лурье С. Российская империя как этнокультурный феномен // ОНС. 1994. № 1. С. 56.

78 Брейфогл Н. Контакт как созидание. Русские сектанты и жители Закавказья в XIX в. // Диаспоры. 2002. № 4. С. 185, 188.

79 Ремнев А.В., Суворова Н.Г. Указ. соч. С. 137. 